\title{
Irrigation for food production in the semi-arid region of northeast Brazil: case studies in Petrolina, Juazeiro, Vale do Açu and Agrovila Canudos in Ceará-Mirim
}

\author{
E. Pereira, S. Rola, M. Freitas \& L. P. Rosa \\ The International Virtual Institute of Global Change and \\ The Energy Planning Post-Graduation Program of the \\ Federal University of Rio de Janeiro, Brazil
}

\begin{abstract}
The aim of this work is to analyze irrigation for food production in the municipal districts of Petrolina, in the State of Pernambuco (PE), Juazeiro, in the State of Bahia (BA), and Vale do Açu and Ceará-Mirim, in the State of Rio Grande do Norte (RN), all of which are located in the semi-arid northeastern region of Brazil. In Petrolina and Juazeiro, the highest productivity rates are achieved in cultivating grapes and mangos, considered the principal fruits for the export market. The infrastructure in the irrigated perimeters includes the availability of water and electric power supply for both large and small producers alike. In Vale do Açu, the 1969 construction of the Armando Ribeiro Gonçalves Dam, with holding capacity of up to 2.7 billion liters of water, sought to enhance conditions for local residents by settling them on the land and making it possible for them to engage in agricultural production in the irrigated perimeter of the Lower Açu River. This region is the biggest producer of bananas in the entire country. In addition, for 8 years now, the Ceará-Mirim Valley has been the location of a farming cooperative called Agrovila Canudos, where 120 families are settled on an area measuring 1.3 thousand hectares. At present, just 19 families work in the cooperative and obtain satisfactory results in irrigated agriculture and other projects, such as fish-farming and cultivation of Jatropha curcas (physic nut) shrubs for use in the production of biodiesel fuel.
\end{abstract}

Keywords: irrigation, semi-arid, food production, and settlement projects. 


\section{Introduction}

On average the farming and livestock-raising industry accounts for roughly $69 \%$ of all fresh water consumed in the world, with $21 \%$ being used by other industries, and the remaining $10 \%$ by households (Clarke and King [1]). Accordingly, in carrying out irrigation projects it is imperative to seek to make the most efficient use of water, cutting down on needless costs and preventing waste (which at times reaches as high as 50\%) in irrigation systems. Accordingly, as irrigation in the semi-arid Northeast Region of Brazil, which has a steppe climate, was considered a vital instrument for fostering economic growth, the first irrigated perimeters were set up in the 1960s at the recommendation of the Food and Agricultural Organization (FAO) of the United Nations. The first pilot projects were commenced in the municipal districts (towns) of Bebedouro and Mandacaru, located in the States of Pernambuco (PE) and Bahia (BA), respectively.

In 1970, the Brazilian Federal Government published the outlines of a national irrigation policy to be implemented through the Multi-Year Irrigation Program - PPI [2]. The National Department for Anti-Drought Projects DNOCS, the former São Francisco River Valley Authority - SUVALE and the current São Francisco River Valley Development Company - CODEVASF (Companhia de Desenvolvimento do Vale do São Francisco) were assigned the task of serving as implementation agencies for this program. Other governmental rural development programs in the semi-arid Northeast region of Brazil were created, as exemplified by the Project for Management of Natural Resources on Cultivated Plains - PROVARZEA and the Program for Financing Acquisition of Irrigation Equipment - PROFIR. Their aim was to expand the possibilities for keeping people on the land and stemming the flood of rural migrants to cities.

Having been established in the locations cited above in the three semi-arid states of the region, considered to be a national priority area, the irrigation projects for production of major crops, covering approximately 500 thousand irrigated hectares, correspond to $14 \%$ of the total irrigated area in Brazil. Of the $61 \%$ of impounded water intended for agriculture in Brazil, chiefly in irrigation projects, just $50 \%$ is effectively consumed by plants. The remaining $50 \%$ is wasted during collection, storage, distribution and application of water in irrigation (ANA, 2004). Therefore, there is tremendous waste in the use of water in irrigated agriculture, which also entails waste of electric power as well. Water losses come about through leakage and during handling, but mainly due to employment of inadequate, technologically backward irrigation systems. There is greater use of systems with lower yields due to the ease of acquiring them in relation to the costs of making new investment in improved technology. As shown in Table 1 below, consumption of water and electric power should be considered a basic element in irrigation projects, considering the value added to production as a result of using these utilities.

This article presents field reports on irrigation for food production in three different watersheds: the lower middle section of the São Francisco River for the Juazeiro/Petrolina complex, the Piranhas-Açu River watershed for the Vale do 
Table 1: Consumption of water and electric power for different crops in a year [Litres and Kilowatt-hours (kWh) per Hectare (ha)] [3, 4].

\begin{tabular}{|l|c|c|}
\hline \multicolumn{1}{|c|}{ CROPS } & $\begin{array}{c}\text { WATER } \\
\text { CONSUMPTION } \\
\text { (litres/ ha) }\end{array}$ & $\begin{array}{c}\text { ELECTRIC POWER } \\
\text { CONSUMPTION } \\
(\mathrm{kWh} / \mathrm{ha})\end{array}$ \\
\hline Cotton & $5,208,000$ & 681 \\
\hline Garlic & $4,870,000$ & 637 \\
\hline Rice & $19,862,000$ & 2,599 \\
\hline Potatoes & $6,176,000$ & 808 \\
\hline Onions & $5,348,000$ & 699 \\
\hline Beans & $4,573,000$ & 598 \\
\hline Fruits & $9,679,000$ & 1,266 \\
\hline Vegetables & $10,288,000$ & 1,346 \\
\hline Watermelons & $11,729,000$ & 1,535 \\
\hline Honey melons & $11,896,000$ & 1,556 \\
\hline Corn & $6,057,000$ & 793 \\
\hline
\end{tabular}

Açu complex and the lower section of the Ceará-Mirim River for the Canudos settlement complex.

\section{Juazeiro/Petrolina irrigation complex}

The irrigation complex that has developed the most in the São Francisco river watershed is located in the riverside cities of Juazeiro and Petrolina, on the south and north banks in the States of Bahia and Pernambuco, respectively. The first studies for implementing irrigation projects were conducted in the 1960s. The Northeast Development Authority - SUDENE, a federal agency responsible for parts of the states of Minas Gerais and Espírito Santo, as well as the Northeast, began investment projects for regional development by implementing two pioneering projects: (i) Bebedouro, which was subsequently expanded by the São Francisco River Valley Authority - SUVALE, with the latter being replaced later by the São Francisco River Valley Development Company - CODEVASF; and (ii) Mandacaru, the first irrigation settlement in 1968. Besides the Irrigated Perimeters of Bebedouro and Mandacaru, this region also includes the irrigation areas of Curaçá, Maniçoba, Tourão and Senador Nilo Coelho, for a total of $41,458.60$ ha in operation. Furthermore, additional projects are also in the works in Salitre and Pontal, the total area of which will eventually amount to 39,167 ha. Of this total, 8,680 ha have already been implemented. The region has enormous potential for agriculture and also boasts a fish-farming station at Bebedouro. The main products and agricultural projects, as well as the private agribusiness concerns of this complex are broken down in Table 2 below: 
Table 2: Distribution of products and agribusiness projects per company [5].

\begin{tabular}{|l|l|}
\hline Products & Company \\
\hline Fruits (chiefly grapes) & $\begin{array}{l}\text { Agropecuária Lambrunier, Brasiluvas, Juazeiro } \\
\text { agro-cooperative, FRUTIMAG, FRUTIVALE, } \\
\text { FRUTIVITA, Jofra Agrícola, Logos Butiá, } \\
\text { Metaexport, Special Fruit, Timbaúba Agrícola } \\
\text { and Vale das Uvas }\end{array}$ \\
\hline Grapes, wine and vinegar & Fazenda Milano and Minhoto \\
\hline Basic seeds and fruit saplings & Embrapa Semi-árido \\
\hline Alcohol, sugar and mangos & Agrovale \\
\hline Fruit pulp & Niagro Nishieri and Vita Polpas \\
\hline Honey and sweets & Melvale \\
\hline Processing of hides and leather & Curtumes Campelo and Moderno \\
\hline Industrial pepper processing & Seifun Comércio e Indústria \\
\hline Wine & $\begin{array}{l}\text { Santa Maria and Lagoa Grande wine-growers; } \\
\text { Vale do São Francisco, Miolo and } \\
\text { Lovara/Benec wineries; Bianchetti \& Tedesco } \\
\text { and Chateaux Ducos wine cellars }\end{array}$ \\
\hline
\end{tabular}

\subsection{São Francisco River Valley Development Company- CODEVASF}

Through the 6th and 3rd Regional Superintendent's Offices (SR) in the states of Bahia and Pernambuco, CODEVASF has been in charge of implementing and following up on the projects developed in the irrigated perimeters of the Juazeiro-Petrolina Complex. These perimeters are located in the lower middle section of the São Francisco River and the complex includes plots of land owned by both large and smaller producers, classified as such according to the area of land occupied and productivity ratios, among other factors. The JuazeiroPetrolina Complex is involved in the export market, mainly the production of mangos and grapes. Production of these crops requires greater involvement on the part of male and female workers during the planting and harvesting seasons. In these phases of the production cycle, the small producers contribute by supplying additional labour on the plots of land owned by the large producers. The latter, chiefly owing to their better economic situation, among other factors, invest in irrigation systems that are more enhanced and technologically more appropriate. This leads to better use of the water in their systems. By the same token, the small producers use more rudimentary and technologically backward techniques, which besides incurring higher costs per hectare also lead to wasted water. Attempts have been made by smaller producers to work together in cooperatives, but operational difficulties have cropped up, in that such arrangements are generally not part of the local cultural traditions and there are also difficulties in obtaining the financial resources for implementing such group efforts. In the Maniçoba Irrigated Perimeter the attempt at cooperative sale of the local produce involves construction of a "packing house" (Sheds set up for selection, packaging and distribution to market) to which the harvests are hauled, then selected and packaged for distribution to the export market. A private 
packing house has been set up on one of the plots of land belonging to a large producer in another perimeter and this modus operandi has proven to be an efficient one, underscoring the financial potential of exporting to foreign markets. Export sales are carried out as the windows of foreign trade are opened. Particular attention is paid to demands of purchasers, with quality and visual presentation being determining factors for acceptance of the fruits. Payments by importers only occur after the merchandise is received, probably one of the justifications for the careful process of selecting and packaging the fruits.

\subsection{Irrigation projects - irrigated perimeters}

The Irrigation Projects or Irrigated Perimeters can be public, private or mixed operations. They feature irrigation infrastructure that generally includes adduction (water delivery) systems as well as the components required for distribution of water to the irrigation systems on the plots of land. The systems are either individual or company projects. Projects where the irrigation infrastructure is planned, designed and built with direct or indirect operation by a public agency are considered Public Projects. Those in which the infrastructure is implemented and operated by farmers, with or without government assistance, are considered Private Projects.

\subsubsection{Maniçoba irrigation perimeter}

The field study conducted on Irrigation for Food Production involved calls on the owners of the plots of land and entities involved in the process, with the interviews and questions related to the Irrigation Perimeters being subsequently analyzed. The survey results shown in Table 3 refer to the data on the Maniçoba Irrigated Perimeter.

\subsubsection{Tourão irrigation perimeter}

The survey results shown in Table 4 refer to the data on the Tourão Irrigated Perimeter.

\subsubsection{Salitre irrigation perimeter}

The total investment involved in this project is on the order of $\mathrm{R} \$ 900$ million, with part of it being covered by the federal governments Accelerated Growth Program (PAC). The forecast is that the gross value of the output from the project will be on the order of $\mathrm{R} \$ 350$ million per year. During the first stage of the project it is expected that in 2009 irrigation farmers will occupy 255 small plots of land, with 6.6 ha intended for family farmers and 18 plots for mediumsized companies. The latter will receive their plots with just the irrigation and power hook-ups installed, while the small farmers will have available on their plots pressurized water hook-ups, electric power supply and also financing for acquisition of irrigation kits that are appropriate for their crops. It is expected that during this stage 5 thousand direct and 10 thousand indirect jobs will be created $[7,8]$. The survey results shown in Table 5 refer to the data on the Salitre Irrigated Perimeter. 
Table 3: Data relating to the Maniçoba irrigated perimeter [6].

\begin{tabular}{|c|c|}
\hline Region of the & Lower Middle section of the São Francisco. Juazeiro - BA. \\
\hline $\begin{array}{l}\text { Average } \\
\text { annual rainfall }\end{array}$ & $435 \mathrm{~mm}$. \\
\hline Rainy season & 4 months, from December to March (Southern Hemisphere summer) \\
\hline $\begin{array}{l}\text { Average } \\
\text { potential } \\
\text { evapo- } \\
\text { transpiration } \\
\text { (Hargreaves } \\
\text { model) }\end{array}$ & $2,080 \mathrm{~mm}$ per year \\
\hline $\begin{array}{l}\text { Average water } \\
\text { deficit }\end{array}$ & $1,645 \mathrm{~mm} /$ year \\
\hline $\begin{array}{l}\text { Area } \\
\text { implemented }\end{array}$ & $\begin{array}{l}4,293 \text { ha, occupied by } 234 \text { plots owned by small producers on } 1,889 \\
\text { ha and } 80 \text { plots owned by companies on } 2,379 \text { ha. }\end{array}$ \\
\hline Crops & $\begin{array}{l}\text { Avocados, pumpkins, acerolla berries, bananas, eggplants, hog } \\
\text { plums, sugarcane, Chinese gooseberries, onions, coconuts, beans, } \\
\text { figs, guavas, custard apples, oranges, lemons, manioc (cassava), } \\
\text { mangos, passion fruits, watermelons, honeydew melons, corn, } \\
\text { peppers and sweet apples. }\end{array}$ \\
\hline $\begin{array}{l}\text { Irrigation } \\
\text { techniques }\end{array}$ & Infiltration through furrows, aspersion, micro-aspersion and dripping \\
\hline $\begin{array}{l}\text { System for } \\
\text { collection, } \\
\text { distribution } \\
\text { and storage }\end{array}$ & $\begin{array}{l}\text { The water for irrigation is impounded in the São Francisco river } \\
\text { through a pumping station equipped with seven pumps with total } \\
\text { installed capacity of } 3,165 \mathrm{kw} \text { and pumping capacity of } 6.43 \mathrm{~m}^{3} / \mathrm{s} \text {. } \\
\text { Two other stations, with a total of four pumps and total installed } \\
\text { power of } 243 \mathrm{kw}, 8.8 \mathrm{~km} \text { of carbon steel water mains and } 156.2 \mathrm{~km} \\
\text { of concrete-lined canals, distribute water to the plots of land. Ten } \\
\text { offset reservoirs are located along the canal network, four with } \\
\text { accumulation capacity of } 20,000 \mathrm{~m}^{3} \text { each and six with } 10,000 \mathrm{~m}^{3} \\
\text { each. }\end{array}$ \\
\hline $\begin{array}{l}\text { Drainage } \\
\text { system }\end{array}$ & $\begin{array}{l}\text { The drainage system is comprised of } 97 \mathrm{~km} \text { of surface drains and } \\
\text { underground drains on } 500 \text { ha, lowering the water table and } \\
\text { preventing salinization of the more vulnerable areas, with significant } \\
\text { boost in crop productivity. }\end{array}$ \\
\hline Road network & The internal road network has a total length of $222.9 \mathrm{~km}$. \\
\hline $\begin{array}{l}\text { Housing and } \\
\text { administrative } \\
\text { centres }\end{array}$ & $\begin{array}{l}\text { The irrigation perimeter features two housing centres hooked up to } \\
\text { drinking water supply. They both feature a technical-administrative } \\
\text { centre, a social gathering place, a commercial area, two schools, two } \\
\text { health centres, two telephone centres and a police station. Some } \\
\text { producers live in hamlets near the perimeter. }\end{array}$ \\
\hline Job creation & 5,000 direct jobs and 10,000 indirect jobs. \\
\hline
\end{tabular}


Table 4: $\quad$ Data related to the Tourão irrigated perimeter [6].

\begin{tabular}{|c|c|}
\hline Region of the & Lower-Middle section of the São Francisco. Juazeiro - BA. \\
\hline $\begin{array}{l}\text { Annual } \\
\text { average } \\
\text { rainfall }\end{array}$ & $435 \mathrm{~mm}$ \\
\hline Rainy season & 4 months, from December to March (Southern Hemisphere summer) \\
\hline $\begin{array}{l}\text { Average } \\
\text { potential } \\
\text { evapo- } \\
\text { transpiration } \\
\text { (Hargreaves } \\
\text { model) }\end{array}$ & $2,080 \mathrm{~mm}$ per year \\
\hline $\begin{array}{l}\text { Average water } \\
\text { deficit }\end{array}$ & $1,645 \mathrm{~mm} /$ year \\
\hline $\begin{array}{l}\text { Area } \\
\text { implemented }\end{array}$ & $\begin{array}{l}\text { Area measuring } 10,710 \text { ha, occupied by } 37 \text { plots of land owned by } \\
\text { small farmers on } 211 \text { ha and } 14 \text { plots of land owned by companies on } \\
10,499 \text { ha. In the latter category, AGROVALE and FRUTIVALE } \\
\text { stand out. At first the area irrigated measured } 10,688 \text { ha, though it is } \\
\text { being expanded by another } 2,500 \text { ha, which will result in a total } \\
\text { irrigated area of } 13,188 \text { ha, } 2,478 \text { ha of which is under construction } \\
\text { and } 10,710 \text { ha is already implemented. }\end{array}$ \\
\hline Crops & $\begin{array}{l}\text { Pumpkins, bananas, sugarcane, onions, coconuts, beans, guavas, } \\
\text { lemons, papayas, mangos, passion fruit, honeydew melons, corn, } \\
\text { peppers, tangerines, tomatoes and grapes. Sugarcane cultivation } \\
\text { predominates, with production being processed locally at the } \\
\text { Mandacaru Mill owned by AGROVALE. It has the capacity to turn } \\
\text { out two million bags of sugar } 15 \text { million liters of alcohol biofuel. }\end{array}$ \\
\hline $\begin{array}{l}\text { Irrigation } \\
\text { techniques }\end{array}$ & $\begin{array}{l}\text { Infiltration through furrows, micro-aspersion, dripping and central } \\
\text { pivot. }\end{array}$ \\
\hline $\begin{array}{l}\text { System for } \\
\text { impoundment, } \\
\text { distribution } \\
\text { and storage }\end{array}$ & $\begin{array}{l}\text { The source of water is the São Francisco River. The water is } \\
\text { impounded by a pumping station with expanded pumping capacity of } \\
19.8 \mathrm{~m}^{3} / \mathrm{s} \text { : the station features nine pumps with } 6,705 \mathrm{kw} \text { installed } \\
\text { capacity. The distribution network features } 65 \mathrm{~km} \text { of lined canals } \\
\text { and four pumping stations, also with expanded capacity, for a total of } \\
31 \text { pumps and } 9,415 \mathrm{kw} \text { installed capacity, which distributes the } \\
\text { water to the irrigated areas. The expansion projects consist of } \\
\text { increasing the discharge of the main structures: boosting the pumping } \\
\text { capacity of the five stations, with construction of five annex stations } \\
\text { and the section of canals, with elevation of the edges. }\end{array}$ \\
\hline $\begin{array}{l}\text { Drainage } \\
\text { system }\end{array}$ & The drainage network has a total length of $45 \mathrm{~km}$. \\
\hline $\begin{array}{l}\text { Road and } \\
\text { electric power } \\
\text { network }\end{array}$ & $\begin{array}{l}\text { The road network has a total length of } 42 \mathrm{~km} \text {, while the electric } \\
\text { power lines extend for } 49 \mathrm{~km}, 17 \mathrm{~km} \text { of transmission lines and } 32 \mathrm{~km} \\
\text { distribution. }\end{array}$ \\
\hline $\begin{array}{l}\text { Housing and } \\
\text { administrative } \\
\text { centre }\end{array}$ & $\begin{array}{l}\text { The perimeter features a housing centre where the technical- } \\
\text { administrative centre is located along with a school; there area also } \\
\text { four other housing centres, four schools and a health centre built by } \\
\text { AGROVALE for its employees. }\end{array}$ \\
\hline Job creation & 10,000 direct jobs and 30,000 indirect jobs. \\
\hline
\end{tabular}


Table 5: $\quad$ Data relating to the Salitre Irrigated Perimeter [6].

\begin{tabular}{|c|c|}
\hline Region of the & Lower-Middle São Francisco. Juazeiro - BA \\
\hline Administrative agency: & CODEVASF \\
\hline Average annual rainfall & $435 \mathrm{~mm}$ \\
\hline Rainy season & 4 months, from December to March \\
\hline $\begin{array}{l}\text { Average potential evapo- } \\
\text { transpiration (Hargreaves model) }\end{array}$ & $2,080 \mathrm{~mm}$ per year \\
\hline Average water deficit & $1,645 \mathrm{~mm} /$ year \\
\hline Area & $\begin{array}{l}\text { The project consists of three irrigation sections. The } \\
\text { feasibility study indicated that that a total of } 23,840 \text { ha } \\
\text { could be irrigated, of which } 5,585 \text { ha are located in the } \\
\text { area belonging to CHESF, } 15,695 \text { ha in Salitre and } 2.560 \\
\text { ha in the FAO section. The cost/benefit ratio has been } \\
\text { calculated at } 1.67 \text { and the internal rates of return at } 20 \% \\
\text { (11\% p.a). During preparation of the basic project, a } \\
\text { further 5,370 ha were incorporated, increasing the area to a } \\
\text { total of } 29,210 \text { ha, with } 23.270 \text { ha being studied or } \\
\text { designed and 5,940 ha under construction, } 5,940 \text { ha in the } \\
\text { CHESF section, } 20,710 \text { ha in Salitre and } 2.560 \text { ha in the } \\
\text { FAO area. The division should be as follows: } 20 \% \text { for } \\
\text { small irrigation farmers ( } 944 \text { plots) and } 80 \% \text { for } \\
\text { companies ( } 485 \text { plots), although it should be mentioned } \\
\text { that the plantation structure should be maintained in the } \\
\text { FAO area. Besides the area for the irrigation project, } \\
13,500 \text { ha have been set aside as a legal reserve and } 1,800 \\
\text { ha as an area for permanent preservation. For construction } \\
\text { purposes, the project has been divided into five stages, } \\
\text { with the first stage (CHESF area measuring } 5,940 \text { ha) } \\
\text { under construction, involving } 330 \text { plots for smaller } \\
\text { irrigation farmers and } 82 \text { plots for companies. }\end{array}$ \\
\hline Crops & $\begin{array}{l}\text { Pineapples, avocados, acerolla, cotton, bananas, sweet } \\
\text { potatoes, beans, guavas, melons, mangos, honeydew } \\
\text { melons, sweet corn, peppers, tomatoes and grapes. }\end{array}$ \\
\hline Irrigation techniques & $\begin{array}{l}\text { Infiltration through furrows, conventional aspersion, } \\
\text { micro-aspersion and dripping. }\end{array}$ \\
\hline $\begin{array}{l}\text { System for impoundment, } \\
\text { distribution and storage }\end{array}$ & $\begin{array}{l}\text { The basic design calls for impoundment from the São } \\
\text { Francisco river through a pumping station equipped with } \\
\text { six pumps and total capacity of } 7,478 \mathrm{kw} \text { at a rate of } 41.95 \\
\mathrm{~m}^{3} / \mathrm{s} \text {; from the impoundment reservoir the water will be } \\
\text { distributed through a network of canals over } 124.9 \mathrm{~km} \text {, } \\
\text { with sections in pipelines and aqueduct. This distribution } \\
\text { network will feature nine pumping stations with a total of } \\
42 \text { pumps and } 45,052 \mathrm{kw} \text { capacity, six large reservoirs and } \\
\text { three smaller ones, each with capacity for accumulating } \\
967,100 \mathrm{~m}^{3} \text { of water. }\end{array}$ \\
\hline Drainage system & $\begin{array}{l}\text { The network will be } 155.3 \mathrm{~km} \text { long, draining the water to } \\
\text { nearby streams through the use of natural drains. }\end{array}$ \\
\hline Road and electric network & $\begin{array}{l}\text { The road network (main and secondary roads) is } 932 \mathrm{~km} \\
\text { long and the electric network is } 190 \mathrm{~km} \text { long, of which } 65 \\
\mathrm{~km} \text { is } 69 \mathrm{kw} \text { and } 125 \mathrm{~km} 13.8 \mathrm{kw} \text {. }\end{array}$ \\
\hline Housing and administrative centre & $\begin{array}{l}\text { Reinforcements are slated for the infrastructure in the } \\
\text { existing locations in the area (field for horses, grove of } \\
\text { acacias and wax palms, etc.) and } 6 \text { service centres. }\end{array}$ \\
\hline Job creation & $\begin{array}{l}29,210 \text { direct jobs, } 58,420 \text { indirect jobs and } 175,260 \\
\text { people benefited. }\end{array}$ \\
\hline
\end{tabular}




\subsection{Undertakings related to irrigation and food production activities}

Irrigated fruit-growing has made it possible for the region to carry out various activities that add up to ensure enhanced productivity and economic growth, the effects of which are seen in the supply of labour, among other factors. The population has increased with the arrival of entrepreneurs, along with both male and female workers in search of this market potential for their labour. The region's promising potential is reflected in the growth of residential areas. In this sense, undertakings have been set up aimed at providing increased support for the principal activity of the irrigated complex that provides the foreign exchange earnings.

\subsubsection{Juazeiro Producers Market - BA}

The Juazeiro Producers Market has been set up on an area measuring roughly $90,000 \mathrm{~m}^{2}$, with expansion already being forecast, and contains 208 boxes and around 500 stalls. Its activities provide support for receiving, distributing and selling part of the region's irrigated fruit-growing production. This is the nation's largest single fruit shipment depot and sells around 80,000 tons of various products per month, involving a total of 44 different types of fruits and vegetables. It is frequented by approximately 35,000 people and 10,000 vehicles each week and an average of 5,800 14-ton trucks per month. The market's webpage discloses statistical information and quotes daily prices to be used as the basis for sales of products by its 1,258 permit-holders, which account for an average of 4,000 direct jobs. Around 5,500 indirect jobs are generated through sales of the production of the small- and medium-sized producers [9].

\subsubsection{Brazilian Mediterranean Fruit Fly Project in Juazeiro -BA}

One of the pests that wreak havoc on the world's fruit crops at both the planting and selling ends of the chain is Ceratitis capitata, known as the Mediterranean fruit fly. This pest attacks a wide variety of tropical, sub-tropical and temperate fruits such as mangos, grapes and guavas, among others, causing annual losses of about R $\$ 150$ million. Fighting this pest at the irrigated fruit-growing complex of Petrolina-Juazeiro has been carried out by using the technique of release sterile fruit flies onto the fields. These sterile insects are produced in laboratories in quantities approximately the same as abound naturally in the crop area. Upon mating with the local female insects, the sterile male fruit flies ensure that the females will not reproduce, thus gradually reducing the quantity of fruit flies in the area where the technique is applied. This project is being coordinated by researcher Antônio Nascimento, of EMBRAPA's Cassava (Manioc) and Tropical Fruit-Growing Division (headquartered in Cruz das Almas - BA), a unit of the Brazilian Agriculture and Livestock-Raising Research Company (EMPRABA). EMBRAPA in turn is linked to the Federal Ministry of Agriculture, Livestock-Raising and Food Supply. The project further receives financial support from the State of Bahia's Research Support Foundation (FAPESB), which is responsible for importing the sterile male pupas from the Mendoza Bioplant in Argentina. Sterile males have also been produced at the first Brazilian Bioplant, called Moscamed Brasil, which occupies a total area of 
60 thousand $\mathrm{m}^{2}$, with five sheds measuring approximately 5 thousand $\mathrm{m}^{2}$, located in Juazeiro - BA. Investment outlays for implementation of this Bioplant have been on the order of R $\$ 17$ million. Personnel are now being trained in using techniques for releasing the insects, maintaining control over quality and appraising the efficiency of the sterile fruit flies, in order to disseminate the technique and uphold phytosanitary standards, which contributes toward exportation of fruits at appropriate quality levels to meet the demands of the consumer market.

\subsubsection{Embrapa Semi-Árido}

Across the river, in Petrolina - PE, is one of the main offices of EMBRAPA. For more than 30 years now, research has been conducted on implementation of techniques that are technically viable for the needs of irrigated agriculture. The office's assets include various technologies and acquired experiences that have been made available to farmers for developing this semi-arid region through enhancement of agricultural processes that are economically and socially sustainable and dynamic as well. Ever since its creation, EMBRAPA Semi-Árido has set up lines of research that generate technologies and information that make it feasible to carry out agriculture and preserve the environment in the region [10]. EMBRAPA Semi-Árido has four experimental fields located in the following perimeters: Caatinga, Bebedouro, Mandacaru and Nossa Senhora da Glória. At the Bebedouro perimeter several experiments are underway, among them adaptation of foreign crops to semi-arid climatic conditions. Among such crops are the Olive Tree (Olea europaea) from the Middle East, the Tahitian Noni or Beach Mulberry (Morinda Citrifolia) from Oceania; the Date Palm (Phoenix dactylifera) from Northern Africa and the Pear (Phoenix Dactylifera) from Europe. Moreover, there are two projects underway for desalinization of the soil and water for production of Tilapia fish and cultivation of old-man saltbush (Atriplex nummularia). Among the other work carried out by EMBRAPA is providing technical guidelines for the region's producers and encouraging diversity of projects and planting other crops.

\subsubsection{Valexport}

VALEXPORT was created in 1988 in order to present the irrigation farmers of the São Francisco river valley, with a view to enhancing quality and boosting production. The basic aim was to make the region competitive in both domestic and international markets, besides making the appropriate adjustments for transportation and integration with the rest of the country. The partners admitted to VALEXPORT are legally independent entities, even though they operate jointly on a basis that is more cooperative than competitive through strategies aimed at a shared objective among its peers. Relations involving trust and reciprocity take on major and fundamental roles in order to obtain competitive advantages, since the makeup of the partners represents the better part of the river valley's agricultural production and exportation [11]. 


\section{Vale do Açu}

The area that comprised the integrated Açu/Mossoró complex measures 6,597 $\mathrm{km}^{2}$, with a population of 305,677 inhabitants and a Human Development Index (HDI) of 0.414. The complex is located in the northeast portion of the State of Rio Grande do Norte (RN), a semi-arid region, and is distributed around the townships of Açu and Mossoró, forming two sub-zones that, according to the complex's conceptions, tend towards integration due to production of irrigated fruits as greater economic specificity of this space [12].

Despite the serious economic crisis in Brazil during the 1980s, there was a concentration of projects in the State of Rio Grande do Norte oriented towards the practice of irrigation. Development came about mainly due to private companies with considerable financial backing that could count on the state government to finance the required local infrastructure. During this period the region's residents sought out plots of land en masse for implementation of irrigation projects for food production. Construction of the Armando Ribeiro Gonçalves Dam (Açu Dam), with storage reservoir capable of impounding 2.7 million $\mathrm{m}^{3}$ of water, took place on the Piranhas-Açu River and indicated probable economic growth of the region in this sector. When the dam works were built in May 1983, since the steps of settling the population remaining from the expropriation proceedings upstream were not carried out, and nor were irrigation projects set up downstream, major national business groups began an intense search for land in the region due to the potential for irrigating the Açu valley [12]. The private companies set up operations and introduced modern technologies for application in agriculture, which developed chiefly with a view to serving the export market. Operations in the lower section of the Açu River, which arose as an unfolding of dam construction, started up in the 1990s but so far have not been consolidated. Indeed, less than half of the 75 irrigation formers originally selected to receive 8-hectare lots have stayed around. These farmers were removed mainly due to the crises involving administration of the perimeter by the state and by the National Department of Works against the Drought - DNOCS. Crops in the region include such fruits as bananas, acerolla berries, papayas, mangos, honeydew melons and watermelons. The irrigation methods carried out include pressure irrigation comprised of different aspersion or dripping systems. Impoundment of the water for irrigation takes place through canals (from the lower Açu or Pataxó) or by pumping of water from the Piranhas-Açu river, which now flows permanently tanks to the Armando Ribeiro Gonçalves Dam.

The need noted is more specific involvement as regards administration of the perimeter, which suffers the lack of technical support, mainly due to inefficient irrigation practices, which raises the salinity of the soil. Such practices make production unfeasible and are among the factors preventing implementation of the subsequent stages of the project for expansion of the perimeter. Lawsuits have even been filed by farmers whose surrounding areas have been affected by the salinization process, which has been caused by - among other factors inefficient drainage in the perimeter plots that receive irrigation from public 
sources. Especially noteworthy in the surrounding area is a populace whose state of need is not conducive with a project that called for leveraging the region's economy, providing better infrastructure and fostering social inclusion of the resident population. Electricity bills for consumption of power distributed to the irrigation farmers' plots are administered by the Lower Açu Irrigation District DIBA. Among other snags this agency is in default with the electric power supplier, which causes difficulties for agricultural irrigation. There is further the need for greater participation by the state and federal governments to supply enhancements in the perimeter, chiefly with respect to the road network which is a hindrance to smooth transportation of produce. More recently, flooding due to heavy rains has been yet another obstacle.

\section{Settlement project-PA: Agrovila Canudos}

Also in the State of Rio Grande do Norte (RN), there is a settlement project underway in the region of the Ceará Mirim, River Valley, in the Ceará Mirim mini-watershed. The settlers work an area measuring 121 ha at a place called Agrovila Canudos. There are a total of 120 families involved, of which 19 manage collective projects that are carried out under the cooperative system. Work has been carried out on 21 irrigated hectares to provide technical guidelines and involve effective participation by the settlers. The latter have been responsible for preparing the land, planting the crops and harvesting them. They also sell their produce - watermelons, papayas, bananas and pumpkins, among other fruits - obtained from the collective plots.

In 2008, the target set was to produce around 100 tons of watermelons and 20 tons of papayas per month, along with 60 thousand bunches of bananas every 15 days and several tons of pumpkins besides [13]. One of the experiments carried out, booked as a success, refers to the farming of tilapia fish in hatcheries that have been built since July 2006 in the perimeter. Funds for building the tanks were obtained through the National Program for Bolstering Family Agriculture - Pronaf, which is coordinated by the Ministry of Agrarian Development - MDA. The investment for construction of 50 hatcheries was on the order of R\$ 1.1 million, of which $\mathrm{R} \$ 7$ thousand goes to each family, which each year as access to a further R \$ 3.5 thousand for maintenance and purchase of fish rations.

PROINFA funds made it possible to carry out the tilapia fish farming project, the trend of which is to increase both productivity and profitability, accruing monthly income of roughly $\mathrm{R} \$ 460.00$ for each family. Average catch is 1.3 thousand $\mathrm{kg}$ of fish, which are sold through the region's municipal agencies, which distribute them to needy families. Each one of the settler families is responsible for six hatcheries and it is expected that a total of 504 hatcheries will eventually be set up in the settlement. According to Livânia Frizon, one of the cooperative members who have been settled since the PA began eight years ago, "the estimate is that by year-end net monthly income of $\mathrm{R} \$ 1,000.00$ will be 
accrued by each one of the 19 families involved in this consortium production of fruits, vegetables and fish".

Besides technical advice and loans, the settles who produce tilapia fish have partnerships to make the project viable with such agencies as Banco do Brasil, the federal government's Zero Hunger Program, Petrobras, Rio Grande do Norte Federal University - UFRN, The Federal Institute for Education, Science and Technology - IFRN, the Technical Assistance and Rural Extension Company EMATER, and the state and municipal governments as well. The seeds of the physic nut shrubs (Jatropha curcas, known locality as Pinho de purge or Pinho manse) contain $38 \%$ oil that can be used as a biodiesel. The shrubs are being cultivated at the settlement in order to optimize the undertaking and contributing to the supply of raw material for alternative energy that will help mitigate the effects of greenhouse gases responsible for global warming.

\section{Technological bottlenecks}

This study has analyzed various difficulties that result in snags to socioeconomic development of the region, as well as wasted efforts and resources that need to be taken fuller advantage of. The most likely indicators of weaknesses, as regards technological environments, techniques with negative impact on the environment, training of human resources working on the projects, as well as socio-cultural and economic aspects, are shown in Table 6 on the following page.

Table 6: $\quad$ Indicators of weaknesses noted per technological environment.

\begin{tabular}{|c|c|}
\hline $\begin{array}{l}\text { Technological } \\
\text { problems }\end{array}$ & $\begin{array}{l}\text { - Obsolete irrigation systems } \\
\text { - Water consumption x irrigation system } \\
\text { - Inadequate infrastructure }\end{array}$ \\
\hline $\begin{array}{l}\text { Techniques / } \\
\text { Environment }\end{array}$ & $\begin{array}{l}\text { - Predatory monoculture } \\
\text { - Low equipment maintenance levels } \\
\text { - Pests } \\
\text { - Inadequate substitution of crops (crop rotation) } \\
\text { - Lack of industrialization (juice plants, for example) } \\
\text { - Inadequate drainage / Inefficiency - salinization of soils } \\
\text { - Complementary production system }\end{array}$ \\
\hline Training & $\begin{array}{l}\text { - Non-existence of water management course / Agribusiness } \\
\text { - Transfer of technology / Know-how }\end{array}$ \\
\hline $\begin{array}{l}\text { Socio-cultural } \\
\text { aspects }\end{array}$ & $\begin{array}{l}\text { - Prejudices } \\
\text { - Poverty among surrounding populace }\end{array}$ \\
\hline $\begin{array}{l}\text { Economic } \\
\text { aspects }\end{array}$ & $\begin{array}{l}\text { - Financing } \\
\text { - Complex international sales } \\
\text { - Middlemen } \\
\text { - High cost of power - Pumping (greater efficiency and alternative } \\
\text { sources) } \\
\text { - Veto over use of green tariff } \\
\text { - Bankrupt perimeter project }\end{array}$ \\
\hline
\end{tabular}




\section{Final considerations}

It is expected that the final considerations will indicate a path to minimize the technological bottlenecks noted in this field study. The hindrances are being overcome through more efficient practices or public policies, with a view to gains from expanding irrigation for food production. One reality that is pervasive and requires urgent solution involves investments in the latest technologies. These technologies should be appropriate for plantations that use irrigation systems capable of optimizing the resources used in agriculture. A need is also perceived with respect to training personnel who need to carry out their activities with technical competence, sufficient academic know-how that raises their consciousness as citizens and makes them oriented towards sustainability of our planet. The Salitre perimeter warrants evaluation as regards full implementation, considering its potential and the financial resources invested so far, which need to allow greater participation by people and generation of more income. The Canudos Project analyzed in this study shows a reality that needs to be disseminated and merits institutional support in correlated projects, given the success of the enterprise obtained through the willpower of the male and female workers involved, as well as participation by the public agency. This study indicates that it is possible to carry out activities in the area of Irrigation for Food Production, provided that there is involvement and promotion of public policies that contribute to execution of the projects in a sustainable manner.

\section{Acknowledgements}

We would like to thank the Ministry of Science and Technology which provided the funds for our research work through the CT-HIDRO Sectorial Fund; the Getúlio Vargas Foundation (FGV), for administrative support throughout the entire project; CODEVASF, especially Mr. Joselito de Souza (Head of the Production Division in Juazeiro) and Mr. Alcides Modesto (Regional Superintendent in Juazeiro) who arranged our travels and opened up doors at the institutions and perimeters visited in the Juazeiro-Petrolina Irrigation Complex; the Ministry of Agrarian Development, especially Mr. Hugo Manso (MDA Delegate for Rio Grande do Norte), who organized our field travels in the Açu River Valley; Mr. Neilton Fidélis (Professor of CEFET-RN and Technical Advisor to the Brazilian Forum on Climate Change) for the support in the field study in the Ceará-Mirim River Valley; the International Virtual Climate Change Institute (IVIG) at the COPPE/UFRJ graduate school for support in development of the research work on Irrigation for Food Production in the Semi-Arid Region of Northeast Brazil; the many technicians who so kindly assisted us in our interviews; and to all the male and female workers who are entrusted with the difficult task of producing in the field to guarantee their sustenance and the possibility of a nation that produces food for its people and development of our country. 


\section{References}

[1] Clarke, R, King, J. (2005) - O Atlas da água: O mapeamento completo do recurso mais precioso do planeta (based on a work originally prepared in English: The Atlas of Water - The complete map of our planet's most precious resource), translated into Portuguese by Ana Maria Quirino and published by Publifolhas, São Paulo 2005.

[2] Valdes, A; Wagner, E; Mmarzall, I; Simas, J; Morelli, J; Pereira, L. P. and Azevedo, L. G. Impactos e externalidades sociais na irrigação no SemiÁrido Brasileiro. Banco Mundial, Brasília: 132p, 2004.

[3] PLANVASF. Plano diretor para o desenvolvimento do vale do São Francisco - Relatório final, Brasília, Brazil, 515 p, 1989.

[4] Christofidis, D. Irrigação, a fronteira hídrica na produção de alimentos (Irrigation, the water frontier in the production of food), Brasília, Brazil 2002.

[5] CODEVASF. http://www.codevasf.gov.br/principal/perimetros-irrigados/ polos-de-desenvolvimento-1/juazeiro-petrolina.

[6] Azevedo, L. G. T. Impactos e Externalidades Sociais no Semi-Árido Brasileiro (Social Impacts and Externalities in the Semi-Arid Region of Brazil), $1^{\text {st }}$ Edition, Brasília, Brazil, World Bank (IBRD), 2004.

[7] MIN. Edital $N^{o} 001 / 2009$ do Ministério da Integração Nacional (Official notice issued by the Ministry for National Integration), 2009.

[8] NV. Notícia do Vale - O Jornal do São Francisco - (March 30, 2009 edition of Valley News, the São Francisco River Valley newspaper) http://www.anoticiadovale.com/ler.asp?id=3073\&canal=4, 2009.

[9] CEASA. Available at http://www.ceasajuazeiro.com.br .

[10] EMBRAPA. http://www.cpatsa.embrapa.br/index.php?op=historia\&mn=1

[11] VALEXPORT. http://www.valexport.com.br/index.php?acao=up

[12] Silva, A. G. Trabalho e Tecnologia na Produção de Frutas Irrigadas no Rio Grande do Norte (Labor and Technology in Production of Irrigated Fruits in RN state) Organized by Cavalcanti, Josefa Salete Barbosa, in Globalização, Trabalho, Meio Ambiente; Mudanças Socioeconômicas em Regiões Frutícolas para exportação. (Globalization, Labor, Environment, Socio-Economic Changes in Export-oriented Fruit-growing Regions), Recife, V.1, p.307-340, 1999.

[13] MDA. http://www.mda.gov.br/index.php?ctuid=12044\&sccid=134 